\title{
Construction of Multi-supply mechanism of environmental public service
}

\author{
Qi Cong ${ }^{1, a}$, Yanqing Xu(corresponding author) ${ }^{2, b}$
}

1 Student of school of politics and public administration in Hainan University, China

${ }^{2}$ Associate professor on theory and practice of public administration, performance management, School of politics and public administration in Hainan University, China

a938269144@qq.com, b sunnyxu611@126.com

Keywords: environmental public service; multi-supply; mechanism; construction

Abstract. Nowdays, one of the realistic topics is the diversification of environmental public service's subject. In the Governance theory, if an effective coordination mechanism is constructed in public service area, government, enterprise, the third party will together take part in the supply of public service. A new multi-supply mechanism of public service and complementation mechanism will be formed through these three subjects' continuous cooperation and competition, giving full play to each one's advantages and complementing each other.

\section{Introduction}

The proposal of environmental public service in China's real economic and social construction of ecological civilization is not out of imagination, but to China's basic national conditions as a starting point and learn from the valuable experience of Western developed countries. On the one hand, in the international context, it's effective measure to mitigate global environmental pollution and ecological damage and it's effective practice to face the necessary trend of global ecological protection doctrine; on the other hand, in the domestic context, it is the inherent requirement for expanding the overall layout of the cause of socialism with Chinese characteristics and the proper meaning for transforming the mode of economic development.

Environmental public service is designed to provide citizens basic protection with a safe, comfortable living environment.According to the urgency of environmental issues and the importance of the public interest involved in various services, the core of environmental public services can be defined as environmental supervision services, environmental management services and environmental emergency services. On the other hand, in order to ensure the validity, comprehensiveness and completeness of the service, the definition of the scope and content of the environmental public service from the point of view of the government to fulfill the responsibility of environmental protection needs to integrate the whole process of environmental protection and environmental protection. Public goods and services that should be provided. Based on this understanding, the scope of environmental public services should also include environmental policy services, environmental information services, environmental education services. The governance theory, forming and rising in 1990s, argues that while the self-organizing power in economy and society areas is developing, the boundary between private enterprises and public department, government and market, government and nongovernment are gradually broke. The entire process of public supply forms into a governance process of complex cooperation network, consisting of various roles. When an effective coordination mechanism is constructed in public service area, a new multi-supply mechanism of public service and complementation mechanism will be formed through these three subjects' continuous cooperation and competition. Government, enterprise, the third party will together take part in the supply of public service, giving full play to each one's advantages and complementing each other.

This research was supported by Hainan Provincial college and university' Scientific research Project (Hnkyzy201404) 
The supply mode of environmental public services can be divided into three types according to the different forms and subject:

The first is the authoritative model,. The main body of the model is the government and its main feature is the operation of power. The second is the market model. The main actors are the private sector and its main feature is market transaction. Individuals can choose between different service providers, while the property rights of goods can be clear. It is also conducive to curb the behavior of consumers free riders and promote the improvement of service efficiency. The third is the voluntary model,. The main body of the model is the third sector and its main feature is the voluntary charitable donations. The government does not play the leading role in the self-governance public service supply mode, but appears as the identity of the order maintainer.

These three modes exist independently and each have advantages and disadvantages. A single model can not meet the needs of environmental public services now, so this paper hopes to build a multi-supply mechanism of environmental public services to solve this situation.

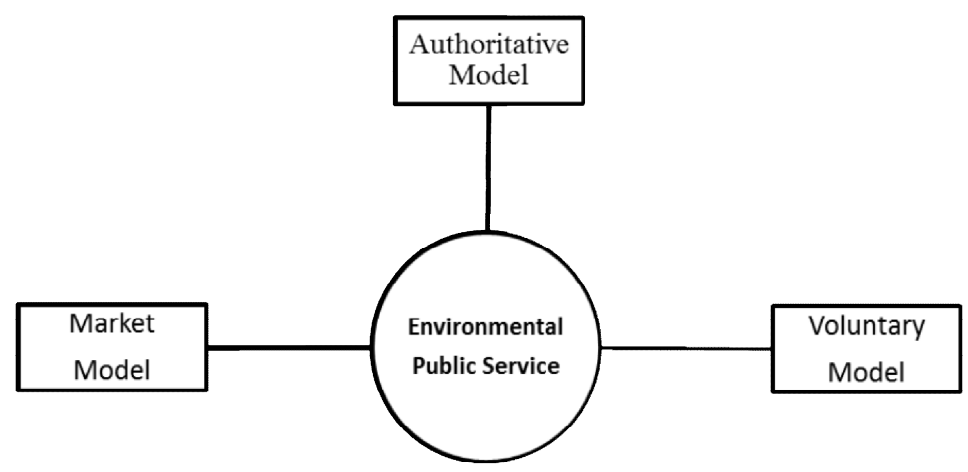

\section{OPTIMIZING THE LEADING ROLE OF GOVERNMENT IN ENVIRONMENTAL PUBLIC SERVICE SUPPLY}

Effectively supplying basic environmental public service is government's inescapable responsibility. It is the necessary one of the suppliers. In the multi-supply mechanism of environmental public service, the role of government needs to change from controller to real server. This is a decisive factor of optimizing government's role of a basic public service supplier, so three following jobs must be done.

A. To classify and decompose the environmental public service

Government failure shows that not all the environmental public service should be government's burden. Government isn't good at some basic environmental public service or some parts of one service. Thus, we need to classify and decompose environmental basic public service, on which basis, government's role will be newly understood. The purpose of classification is to clarify government's advantages and disadvantages in supply. The main function of decomposition is to draw a clear distinction among supplier (arranger), producer and consumer in environmental basic public service, that is consumer directly approach to or get service, which can be individual, people in certain area, governmental organization, private organization, social class with common features, or governmental organization with assisting service. Producers directly arrange manufacture, or directly supply service, which can be government, enterprise, nonprofit organization, or individual, while usually the arranger is government. For example, government and a nongovernmental organization signed a contract, which appoints nongovernmental organization to supply environmental basic public service for certain community. In this case, government is the arranger, nongovernmental organization is the producer and the community is the consumer.

B. Arrange the purview of authority in environmental public service supply of government of different levels reasonably, make sure and confirm them through law 
According to level of environmental public service, environmental public service relating to whole country interests such as environmental protection investment, environment protection and so on should be offered by central and provincial government, and the local government is majorly responsible for offering regional environmental public service such as regional environmental improvement and so on.

C. Select the tools for environmental public service supply cautiously

For realizing policy goal of environmental public service supply, government has many choices. According to Michael Howlett and M.Ramesh's classification, policy tools can be classified into voluntary approaches, including family, community, voluntary organization and market, mixed tools and compulsory instruments. The mixed tools include information, convincement, subsidy, transaction of property right, tax revenue, and charge for use. At the same time, the compulsory tools consist of governmental control, environmental public service and direct supply. Various tools have different merits and drawbacks, so when offering public service, the government should take cautious and all-round consideration choosing appropriate policy tool and how to make the best of them.

\section{INTRODUCING MARKET INTO ENVIRONMENTAL PUBLIC SERVICE SUPPLY}

The leading role of government in environmental public service supply doesn't mean that market is excluded. Harold Demsetz points out that assuming without free consumption, private enterprise can effectively offer public goods. That is to say, if exclusiveness exists, private individual can offer certain public goods well. Some environmental public service is of complexity in their nature, which is not only like public goods, but also like private goods. To introduce market mechanism into these goods is not only probable, but also necessary, so introducing market and competition mechanism properly, setting up effective interests share mechanism, inspiring market's enthusiasm, and protecting investors' legal rights in investing environmental basic public service are of important practical significance and feasibility for construction of multi-supply mechanism of environmental public service. For instance, government can transfer all or part of management right to market through public-private joint management, private contractual operation, PPP(Public-Private-Partnership),BOT(build-operate-transfer) and other methods, when constructing public facility projects. In this way, public and private cooperate with each other, sharing government's burden of investment and management.

To improve environmental public service through introducing market mechanism, firstly, property should be clarified, which is the premise that private organization and enterprise participate in supply. Secondly, tax preference policy should be used. Because enterprises are after profit, and tax is closely related to the income of enterprise, government should increase enterprise's income to enhance their enthusiasm in participating in basic environmental public service supply in rural places through preference policy and tax deduction in basic environmental public service investment.

However, since the inherent drawbacks of market, the market supply of environmental public service should be supervised and guided by government instead of self-deciding or blindly offering only by market. First of all, the government should play role of supervisor, preventing new monopoly, negative offer, vulnerable groups, or region excluded happening. What's more, the government also need to play a role of public policy guide, leading market to effective and equalized basic environmental public service supply.

\section{DEVELOPING NONGOVERNMENT ORGANIZATION'S POWER IN ENVIRONMENTAL PUBLIC SERVICE SUPPLY}

In China, environmental public service supply often decides supply amount, structure and approach according to self-preference or achievements in official career, in the pressure mechanism. As a result, the public's demand actually doesn't get enough attention they deserved. Simple, unbalanced supply mechanism is hard to satisfy the actual demand of basic environmental public service, leading to supply be apart from demand of service. Nongovernmental organization supplements the financial deficiency in basic environmental public service supply of government, 
bringing vulnerable groups and micro areas which government usually doesn't take care into consideration. It also makes up the deficiency of government in supplying basic environmental public service. Furthermore, it promotes social welfare, and enhances social equality. Therefore, in the circumstance that government lacking power and difficult to supply basic environmental public service effectively, encouraging social power, adopting government finance, and nongovernmental organization contract become important idea for solving environmental public service demand.

Since it is necessary and feasible for environmental NGOs to participate in government environmental public services, a reasonable model is an urgent requirement for research. Practice shows that environmental NGOs are still defective in the process of participating in supply of environmental public service, which also requires the combination of government and enterprises to provide environmental public services in the process of supply of environmental public services. On this basis, the environmental NGOs involved in model of environmental public service are divided into two types, namely, leading and auxiliary type.

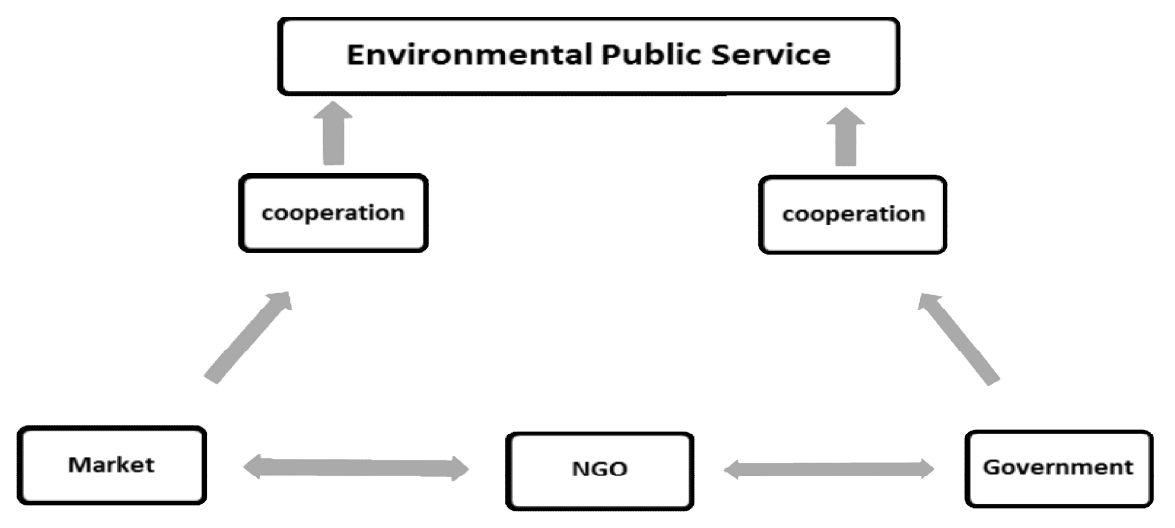

A means that in the field of market failure and government failure, environmental NGOs can provide environmental public services separately. The process can be realized by collecting membership fees, paying users and issuing lottery tickets. This mode is the leading type. In the figure, "B" indicates that, in case of lack of legitimacy, imperfect institutional mechanism, lack of funds and talents, it can cooperate with the government through contracting, franchising,etc., to jointly provide environmental public services. Figure $\mathrm{c}$ shows that the same NGO failure in the case of environmental protection, the market can also cooperate with NGOs, learn from each other, to provide services to meet public demand. In B and C, NGOs are supported by the government or the market and participate in the provision of public services, so the model is called auxiliary.

However, nongovernmental organization in China comes across bottleneck nowadays. Legality, organization ability and public reliance seriously inhibit further develop for Chinese nongovernmental organization. Through invest in social capital is another strategy, also an effective strategy, for developing nongovernmental organization. According to definition, social capital mainly contains cooperation rules, reliance and network. So the core of the strategy that investing in social capital is for more abundant social capital, higher public recognition and reliance, boarder social relationship network, and better cooperation among government, enterprise and the public.

\section{CONCLUSION}

At present, China is in the period when people's demand for basic environmental public services is increasing, but the supply of basic environmental public services is not enough. Therefore, the promotion of equalization of basic environmental public services has become an important task in the management of all levels of government. The supply of environmental public service is an important part of the basic public service supply. It is still a new research field, which is the focus of all countries in the world. It is also a new subject of public management and social development in our country. 
In the Governance theory, market subjects, government subjects, nongovernmental organization and other suppliers' multiplication are the necessary trend. By analyzing the background of China's ecological civilization construction and rationalizing the basic concept of environmental public services, this paper starts from the supply of environmental public services, that is, from optimizing the government's leading role in public service supply, introducing market forces to improve the supply of public services, non-governmental organizations to participate in public service supply three aspects to construct the environmental public service multi-supply mechanism.

\section{References}

[1] Yanqing, The Construction of Socialist Civilization with Chinese Characteristics and Its Theoretical Basis. University of Science and Technology of China, 2015.(In Chinese)

[2] Jianwei Zhang, Some Thoughts on Scientific Setting of Government Environmental Responsibility. China Population, Resources and Environment, 2008,18 (1): 193 - 196.(In Chinese)

[3] Wangyu, Lili Fan, The Connotation and Evaluation of Equalization of Environmental Public Service.China Population, Resources and Environment, 2012,08:55-62.(In Chinese)

[4] Yongjia $\mathrm{Hu}$, Research on the Dilemma and Countermeasures of Environmental NGOs Participating in Government Public Service. Nanjing University of Science and Technology,2013.(In Chinese)

[5] Juhua, The Current Theory, Methods and Technology of Market Mechanism in Public. Peking University Press, 2009:247.(In Chinese)

[6] Tangjuan, Fuguo Cao, An Analysis of the Multivariate Mode of Public Service.Journal of Huazhong Normal University, 2004(2).(In Chinese)

[7] HowlettRamish, Public Policy Research - Policy Cycle and Policy Subsystem.2006,144:169.

[8] HongyuanZuo, The Multi - supply of Rural Public Goods from the Perspective of Local Governance. Journal of Shenyang University.2009,03.(In Chinese)

[9] Liren Dong, Innovation of Urban and Rural Basic Public Service Supply. Decision - making exploration,2009(01).(In Chinese)

[10] Shiwei Chen, A Study on the Construction of Diversified Participation Mechanism of Rural Public Service Providers in China. Realistic,2010(01).(In Chinese)

[11] Weitao, On the Equalization of Basic Public Service from the Perspective of Privatization.Theoretical research,2007(05).(In Chinese) 